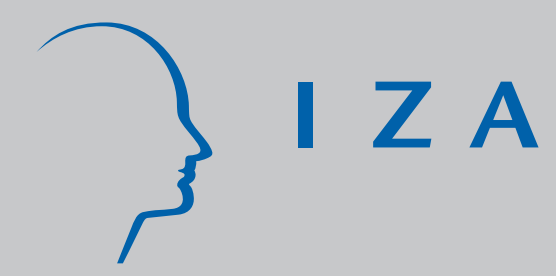

IZA DP No. 8062

Forty Years of Immigrant Segregation in France, 1968-2007: How Different Is the New Immigration?

Jean-Louis Pan Ké Shon

Gregory Verdugo

March 2014 


\title{
Forty Years of Immigrant Segregation in France, 1968-2007: How Different Is the New Immigration?
}

\author{
Jean-Louis Pan Ké Shon \\ CREST-LSQ \\ Gregory Verdugo \\ Banque de France \\ and IZA \\ Discussion Paper No. 8062
March 2014 \\ IZA \\ P.O. Box 7240 \\ 53072 Bonn \\ Germany \\ Phone: +49-228-3894-0 \\ Fax: +49-228-3894-180 \\ E-mail: iza@iza.org
}

Any opinions expressed here are those of the author(s) and not those of IZA. Research published in this series may include views on policy, but the institute itself takes no institutional policy positions. The IZA research network is committed to the IZA Guiding Principles of Research Integrity.

The Institute for the Study of Labor (IZA) in Bonn is a local and virtual international research center and a place of communication between science, politics and business. IZA is an independent nonprofit organization supported by Deutsche Post Foundation. The center is associated with the University of Bonn and offers a stimulating research environment through its international network, workshops and conferences, data service, project support, research visits and doctoral program. IZA engages in (i) original and internationally competitive research in all fields of labor economics, (ii) development of policy concepts, and (iii) dissemination of research results and concepts to the interested public.

IZA Discussion Papers often represent preliminary work and are circulated to encourage discussion. Citation of such a paper should account for its provisional character. A revised version may be available directly from the author. 


\title{
ABSTRACT
}

\section{Forty Years of Immigrant Segregation in France, 1968-2007: How Different Is the New Immigration?}

\begin{abstract}
Analysing restricted access census data, this paper examines the long-term trends of immigrant segregation in France from 1968 to 2007. Similar to other European countries, France experienced a rise in the proportion of immigrants in its population that was characterised by a new predominance of non-European immigration. Despite this, average segregation levels remained moderate. While the number of immigrant enclaves increased, particularly during the 2000s, the average concentration for most groups decreased because of a reduction of heavily concentrated census tracts and census tracts with few immigrants. Contradicting frequent assertions, neither mono-ethnic census tract nor ghettoes exist in France. By contrast, many immigrants live in census tracts characterised by a low proportion of immigrants from their own group and from all origins. A long residential period in France is correlated with lower concentrations and proportion of immigrants in the census tract for most groups, though these effects are sometimes modest.
\end{abstract}

JEL Classification: J61

Keywords: immigration, spatial segregation, France

Corresponding author:

Gregory Verdugo

Banque de France

31 rue Croix-des-petits-champs

75049 Paris Cedex 01

France

E-mail: gregory.verdugo@banque-france.fr

\footnotetext{
* The authors accessed the Census data via the Centre d'accès sécurisé distant (CASD), dedicated to the use of authorized researchers, following the approval of the Comite français du secret statistique. This research was partially supported by a French State grant ANR-10- EQPX-17 (Centre d'accès sécurisé aux données - CASD). We thank three anonymous referees for insightful comments. JeanLouis Pan Ké Shon would also like to thank Loïc Wacquant for his comments during discussions in the early stage of this project. This paper does not necessarily reflect the views of the Banque de France.
} 


\section{Introduction}

Many observers believe that immigrant segregation in France and in Western Europe has generally intensified during recent decades. High levels of spatial segregation and even ghettoisation could prevent the integration of immigrant minorities into their host society, thus causing them to live "separate lives" across fragmented communities. In this view, spatial segregation correlates with increased risks of interethnic conflicts, thereby threatening the social cohesion of Western societies. These negative assumptions have disseminated throughout the political spectrum and have unsurprisingly influenced several European researchers (for a critical analysis of these views, see Wacquant, 1989, 2007; Peach, 1996, 2009; Simpson, 2007).

However, the focus of many ethnographic studies on civil unrest in the most deprived and segregated neighbourhoods, such as Clichy-sous-Bois (e.g., Kepel, 2011 and to a lesser extent Lagrange, 2006; Lapeyronnie, 2008), produces a distorted image of segregation compared with the realities of segregation, which are considerably less dramatic for most immigrants. In practice, most recent research on France overlooks the silent integration of many immigrants and their uneventful presence in neighbourhoods where various ethnic groups live near a majority of native-born people (Verdugo, 2011).

In addition, several dimensions of the spatial incorporation of immigrants in France remain unexplored. Although recent research has documented the concentration of immigrants across municipalities (Safi 2009) and across the neighbourhoods of Paris (Préteceille 2009), other crucial aspects, such as the proportion of the population groups living in immigrant enclaves and the effect of the length of stay in the host country, remain imperfectly known. Moreover, there is no consistent long term measure of the evolution of immigrant segregation at a geographical level below the municipality allowing us to analyse how various dimensions of immigrant segregation have evolved over time. 
In this paper, we extend the literature by documenting the evolution of immigrant segregation in France using the most uniform possible measures of segregation at the census tract level over 39 years, from 1968 to 2007 . The retrospective examination of segregation over a long period of time and across different groups of immigrants provides a broad overview of segregation during a period of important changes in the composition of immigration. Similar to many European countries, the proportion of immigrants from southern Europe has decreased, and non-European immigration has become predominant. These compositional changes had important consequences in the relative proportion of each group in the population and hence on segregation patterns, which merit exploration.

We first describe the relationship between our study and the existing debates in Europe or elsewhere on immigrant segregation (Section 1) and then describe the data and methods used (Section 2). Economic circumstances have been considerably more disadvantageous for Sub-Saharan and North African immigrants who arrived since the mid1970s than for their predecessors. In addition, the former's average length of residence in France has been briefer compared with southern European immigrants (Section 3). By analysing restricted access data from the most recent six French censuses, we find that the concentration of immigrants from Maghreb and southern Europe across census tracts decreased between 1968 and 1990 and that it has remained broadly constant or increased slightly from 1990 to 2007. In an apparent paradox, the increased proportion in the population of immigrants from Maghreb or Portugal accompanied a rapid reduction in the concentration of these groups during the 1970s (Section 4).

A close examination of spatial concentration in 2007 also reveals that segregation in France is not mono-ethnic, whether Arab or African (Section 5). The overwhelming majority of immigrants live in census tracts in which the proportion of their national group in the population is less than $5 \%$. 
Over the studied period, the average proportion of immigrants in the census tract tends to increase, particularly during the 2000 s, reflecting, in part, their increase in the in the population. However, most immigrants are living in census tracts where immigrants from all origins are not disproportionately overrepresented. In 2007, only one-fifth of immigrants lived in census tracts comprised of more than $30 \%$ immigrants that are often conventionally defined as immigrant enclaves, whereas most immigrants live in census tracts where immigrants are considerably less concentrated (Section 6).

Finally, we quantify, for different cohorts of immigrants observed in 1999 and 2007, how much the concentration and the proportion of immigrants in the census tract improves with how long they live in France (Section 7). We find that concentration and isolation diminish with length of residence for non-European immigrants but that these trends tend to vary between groups and are sometime modest.

\section{1 - The mechanics of immigrant segregation from a European perspective}

The segregation of immigrants partly reflects the fact that their characteristics differ from those of natives in various aspects. Many immigrants have social traits that are less favourable for employment (i.e., lower education level or language ability) and tend to be more sensitive to economic downturns. However, the matching of housing costs and incomes is moderated by many other forces (Farley, 1995). In particular, housing discrimination affects immigrants by limiting the access to some neighbourhoods because of the systemic action of private landlords or local public housing authorities (Kirszbaum, 2008; Tanter et Toubon, 1999). Housing policies are also important in Europe, where many immigrants live in social housing (Musterd, 2005). In particular, the accessibility of social housing to immigrants and the spatial distribution of social housing across and within urban agglomerations have been shown to influence the concentration of immigrants between and within cities (Bonnal et al., 2012; Verdugo, 2012). 
The segregation of immigrants must also be interpreted as a dynamic phenomenon due to the contrasting effects of immigrant inflows, outflows and the progressive spatial incorporation of the existing population of immigrants. The length of stay in France varies widely across groups of immigrants who arrived during more and less favourable economic periods. Newly arrived immigrants often live disproportionately in port-of-entry neighbourhoods located in large cities, characterised by a large presence of immigrants (Simpson, 2005; Simpson et al., 2008; Bolt et al., 2008; Zorlu and Mulder, 2010). By contrast, as their economic and social outcomes improve, immigrants already settled tend to incorporate over time through positive residential mobility, which usually implies greater contact with majority members (Massey and Denton 1988).

However, measuring the relationship between incorporation and years of residence is complicated because complete trajectories are, by definition, not observed for recent immigrants, and researchers can only extrapolate the future evolution for more recently arrived cohorts. These complications imply that an investigation of incorporation patterns using cross-section data can generate erroneous conclusions if the data exhibit strong cohort specificities (see e.g., Borjas 1985; Abramitzky et al. 2012).

In addition, neighbourhoods must be perceived as dynamic environments where residential mobility is permanent (Manley and van Ham, 2011). Most neighbourhoods are far from being completely homogenous, either ethnically or socially. Residential mobility and spatial dispersion are major phenomena, even in ethnically concentrated neighbourhoods (Simpson, 2004, 2005, 2007; Simpson et al., 2008). In France, Sweden, Norway and the Netherlands, considerable spatial mobility has been documented, often into neighbourhoods with better characteristics for immigrants of all origins (Bråmå, 2008; Musterd and van Kempen, 2009; Pan Ké Shon, 2010; Andersson et al., 2010), thus suggesting an ongoing, progressive incorporation process. 


\section{2 - Data and methods}

\section{1- Data}

This study uses $25 \%$ sample extracts of the 1968, 1975, 1982, 1990, 1999 and 2007 French population censuses. In contrast to previous censuses, the 2007 census was based on the aggregation of five annual census surveys. While previous longitudinal studies had to rely, for confidentiality purposes, on large spatial divisions such as municipality (Safi 2009), we were able to use a restricted access version containing detailed information on location and nationality at the census block level for all years.

The estimates are calculated at the census tract level, and our aim was to use the most homogenous units possible over time. For the 1999 and 2007 censuses, we use the "Ilots Regroupés pour l'Information Statistique" (IRIS), a socio-spatial division equivalent to a census tract introduced by the "Institut National de la Statistique et des Études Économiques" (INSEE), the French statistical institute in 1999 for municipalities of at least 10,000 inhabitants. It delineates geographic areas with an average population of 2,500, as defined by geographical criteria such as major streets, railway lines and watercourses. However, the IRISs are unavailable for censuses before 1999. To measure the evolution of segregation using a homogeneous level from 1968 to 1990, we constructed "pseudo-IRISs" using information from the location of households at the census block level. ${ }^{1}$ To do so, we designed an algorithm aggregating adjacent census blocks to create a zone with a population of approximately 2,500 inhabitants.

A comparison between indices of dissimilarity estimated with IRISs or pseudo-IRISs in 1999, where IRISs are available and pseudo-IRISs can be constructed, indicates relatively

\footnotetext{
${ }^{1}$ A census block is the smallest geographic unit used by the INSEE. It is a spatial division containing on average 500 individuals.
} 
negligible differences between the two indices; indices obtained with pseudo-IRISs were between 1 and 2 percentage points lower than those obtained using IRISs. These small differences suggest that the use of pseudo IRIS might be relatively innocuous for measuring segregation patterns.

A limitation of the French census data is that the arrival year in France was not collected in censuses prior to 1999. Consequently, when we analyse how the spatial incorporation of immigrants varies with their length of stay in France across cohorts, we must rely exclusively on 1999 and 2007 census data.

\section{2- Measurement of segregation}

Because immigrants are concentrated in large urban areas and rarely reside in rural areas and small cities, the sample is restricted to urban units ${ }^{2}$ containing at least 50,000 inhabitants. We focus on two indices of residential segregation, dissimilarity and isolation, which are related to two crucial dimensions of segregation, evenness and exposure, respectively (Massey and Denton, 1988). The index of dissimilarity (henceforth, ID) estimates the proportion of individuals from a particular group who would need to change the census tract for their group and the rest of the population to be distributed in identical proportions in all census tracts (or other socio-spatial divisions). The index is given by:

$$
I D_{u}=\frac{1}{2} \sum_{i \in u}\left|\frac{G_{i u}}{G_{u}}-\frac{N_{i u}}{N_{u}}\right|
$$

where for each urban unit $u$, the IDs are calculated at the IRIS level $i$, using immigrants of a given national origin or geocultural region with respect to the rest of the population. The term $G_{i u}$ denotes the number of immigrants living in census tract $i$, and $G_{u}$ is the total number of

\footnotetext{
${ }^{2}$ An urban unit is defined by the INSEE as a set of municipalities consisting of a continuous built-up area and a population of at least 2,000 inhabitants.
} 
immigrants in the urban unit. The terms $N_{i u}$ and $N_{u}$ refer to the number of inhabitants in the census tract and in the urban area, respectively who do not belong to the immigrant group, which by definition includes immigrants from other groups.

To calculate the "average" dissimilarity for the entire population of the immigrant group, we follow Cutler et al. (2008) and report the weighted average index of dissimilarity $I D$ across urban units, weighted by the proportion of the immigrant group in each urban unit:

$$
I D=\sum_{u} \frac{G_{u}}{G} \times I D_{u}
$$

where $G$ is the total number of immigrants from a group across all urban units in the population. We exclude urban units with fewer than 500 individuals in the immigrant group from the weighted average $\left(G_{u}>500\right)$.

We measure isolation following Bell (1954) by using the percentage of the immigrant group in the area occupied by the average immigrant from the group. The index is given by:

$$
I_{u}=\sum_{i \in u} \frac{G_{i u}}{G_{u}} \times \frac{G_{i u}}{\text { population }_{i u}}
$$

where population $_{i u}$ refers to the total population of tract $\mathrm{u}$. As for the dissimilarity index, we calculate a weighted average across urban areas using the proportion of immigrants in each urban unit as the weight.

One difficulty in interpreting the dissimilarity indexes is that they might differ from zero even if the group is allocated randomly across units (Carrington and Trostke, 1997). In practice, the risks of obtaining non-zero indexes in the case of a random allocation are substantially larger for small groups. The isolation index is also, by definition, sensitive to the overall size of the immigrant group under consideration. Consequently, longitudinal and cross-sectional comparisons of segregation indices are difficult to interpret unless the groups 
are of equal size in a given year and over time. To address this issue, we estimate the dissimilarity and isolation index that would have been observed for each group in each urban area if the allocation across census tracts had been random. Specifically, we simulate 'random indexes' 10 times to obtain an average random dissimilarity and isolation index. ${ }^{3}$ Then, we calculate an adjusted index using the difference between the observed and the random index for each group. This index can be interpreted as part of the standard index, which cannot be explained by the random allocation of the group across census tracts. ${ }^{4}$

The segregation indices, such as those considered above, are useful to describe the average evolution of segregation across groups and over time. However, as shown by Bell and Machin (2013) in the case of the UK, these indices might conceal important changes in the distribution of immigration across areas. In particular, Bell and Machin (2013) found that it is possible to observe a decrease in average segregation indices and an increase in the proportion of mildly segregated neighbourhoods simultaneously. This can happen if a decrease in the proportion of heavily segregated neighbourhoods outweighs the effect of an increase in the proportion of immigrants in mildly segregated neighbourhoods. To document more clearly how segregation patterns have changed over time, we report, in addition to the indices, the distribution of immigrants across census tracts with different proportions of immigrants from their own group and from all groups in their population.

\section{3 - Limitation of the study}

${ }^{3}$ Because of the large sample size of the census data, the estimates of the average random dissimilarity indexes for all groups require approximately 30 hours per census year. In practice, these simulations exhibited extremely small standard deviations (less than 0.01 for most groups). We also experimented with 50 simulations for certain groups and found the results qualitatively identical.

${ }^{4}$ By definition, the 'random' isolation index approximately equals the share of the immigrant group in the urban area population. Consequently, our approach is equivalent to subtracting the percentage of the group in the total population from the original isolation index, as performed by Cutler et al. (2008). Empirically, both methods yield similar results. 
A limitation of our study is that we cannot include "second-generation immigrants" in the analysis because of data limitations and thus cannot capture how the overall concentration of broadly defined minority groups has evolved over time. ${ }^{5}$ Considering second generations might have an important effect, particularly on isolation indexes, if they tend to live in the same census tract. In 2007, the proportion of descendants in the population was $12 \%$, whereas the proportion of immigrants was $10 \%$.

However, throughout Europe, many studies have emphasised that second-generation immigrants are better incorporated socially and spatially than are their parents. Secondgeneration immigrants, particularly those with one native-born parent (Zorlu and Mulder, 2010), frequently live in census tracts better situated on the socio-spatial scale (Friedrichs, 1998; Musterd and Ostendorf, 2009; Zorlu and Latten, 2009). In France, children of immigrants tend to live in census tracts with lower rates of social housing and lower unemployment compared with those of their parents (Pan Ké Shon and Scodellaro, 2011).

\section{3 - The composition of immigration has changed}

Similar to other European countries, immigration has changed widely during the last decades. From 1968 to 2007, the proportion of immigrants in the population of urban units of more than 50,000 inhabitants increased from $8.6 \%$ to $11.7 \%$, a gross increase of $35 \%$ in 40 years. This change has been gradual, and the total level of immigration in France is near the Western European average. Over this period, the geographical origins of immigrants have also shifted from European to non-European, specifically from southern European to North and SubSaharan African immigrants. The proportion of non-European immigrants in the population has increased in gross terms by $190 \%$, from $2.7 \%$ in 1968 to $7.8 \%$ in 2007 .

\footnotetext{
${ }^{5}$ Data on second-generation immigrants are not collected in French censuses.
} 
Consequently, the arrival period of immigrants aged 18-65 years currently residing in France varies widely according to their origins. In 2007, Italians and Spaniards were the most senior group of immigrants. The median year of arrival for these immigrants is 1966,1973 for the Portuguese, 1986 for Moroccans and Tunisians and 1989 for Algerians and Turks. SubSaharan Africans are the most recently arrived group with a median arrival year of 1993 .

The relationship between length of stay in France and residential integration is therefore currently more unfavourable for North and Sub-Saharan Africans than for southern European immigrants. The period of stay in France also coincides with contrasting economic periods. Most non-European migrants, particularly Sub-Saharan Africans, arrived during periods of high unemployment. Recent studies based on natural experiments have demonstrated that better economic conditions when an immigrant arrives have a lasting effect on the immigrant's subsequent income and correlate with residence in less immigrant-dense areas (Åslund and Rooth, 2007).

\section{4 - Overall reduction in concentration from 1968 to 2007}

From 1968 to 1990, despite an increase in the number and a change in the characteristics of immigrants, the concentration across census tracts has diminished for most immigrant groups (Table 1A). It decreased rapidly from a relatively high level for Algerian and Portuguese immigrants and slightly more moderately for Tunisians, Moroccans, Italians and Spaniards. This decrease is observed using both traditional and adjusted indices. Interestingly, the decrease in concentration occurred between 1968 and 1975, a period when the proportion of North African in the total population increased 52\% (from $1.85 \%$ in 1968 to $2.81 \%$ in 1975).

After 1982, the level of concentration has decreased slightly for southern European immigrants and Algerians and has remained broadly constant for all other non-European immigrants, except Turkish immigrants. Notably, the difference in concentration between European and non-European immigrants has remained unchanged over the period studied; 
adjusted levels of concentrations were approximately 20 points higher in 1968 and 2007 for Algerians and Moroccans compared with Spanish or Italian immigrants.

Turkish immigrants are an important exception to these patterns. Adjusted indices indicate a rapid increase from 1968 to 1982, followed by more moderate increases. These changes are correlated with the large increase in their proportion in the population, a proportion that has quadrupled over the period studied (from $0.14 \%$ in 1968 to $0.53 \%$ in 2007).

The reduction of segregation from 1968 to 2007 is also observed at the geocultural level for immigrants from North Africa and southern Europe (Table 1B). The change during the 1970s is notably different for other non-European groups, which were rare in the population until the 1980 s. Partly reflecting the change in their proportion in the population, a large difference exists between observed and adjusted dissimilarity indexes for immigrants from Sub-Saharan Africa, East Asia and the Middle East. These differences illustrate the importance of correcting the indices when groups with rapidly changing populations are considered. Whereas the adjusted indices increase until 1982, the traditional dissimilarity indexes decrease over the same period by 4 to 13 points.

\section{[Insert Table 1 here]}

The rapid decrease in dissimilarity indexes from 1968 to 1990 for immigrants from southern Europe and Maghreb is consistent with major public policy changes that affected immigrant housing conditions during this decade. During the 1970s, the government granted immigrants access to recently built public housing in an attempt to eradicate immigrant slums located around major French cities. Our results suggest that a considerable spatial diffusion occurred during a relatively brief period when the slums (bidonvilles), where a large proportion of immigrants from Maghreb and Portugal were living, were replaced by more 
varied types of housing, including immigrant workers' hostels, first allocations in social housing (Verdugo 2013) and private-sector accommodation.

\section{5 - A relatively moderate level of isolation from 1968 to 2007}

For the ageing and shrinking groups of immigrants from southern Europe, isolation indices at the national and the geocultural level are low and constantly declining between 1968 to 2007 (Table 2). For non-European groups, isolation indices have increased moderately by less than 2 points for groups with a growing population, such as Morocco or Turkey, have declined for groups from southern Europe and for Algeria and remained stable for Tunisia. These differences partly reflect the effect of changes in the proportion of the groups in the population; corrected indices indicate a slightly smaller increase for Morocco and a more substantial decrease for Algeria.

In Panel B, when measured at the more aggregated geocultural level, the isolation indices tend to increase but, again, corrected indices indicate that this increase largely reflects the increase in the population of the groups. Corrected indices are relatively stable over time, except for East Asia and the Middle East during the 1970s, a period when these groups were rare in the French population.

\section{[Insert Table 2 here]}

Overall, a major insight of these findings is that the isolation indices for nonEuropeans are relatively low during the entire period: they never exceed 5\%, when groups are defined at the national level, and $10 \%$, when defined at the geocultural level. In addition, the indices are sometimes declining, and more importantly, no dramatic change was observed in observed or corrected isolation during the period for most groups despite the fact that the proportion of non-European immigrants in the population multiplied by 2 during the period. 
A detailed analysis of the proportion of immigrant groups across census tracts in 2007 debunks certain myths, such as the existence of mono-ethnic census tracts leading to the existence of ghettos in France. Sixty percent of Algerians live in census tracts, where they account for less than $5 \%$ of the population (Fig. 1). Fewer than $10 \%$ of Algerian immigrants live in census tracts, where their group represents more than $10 \%$ of the population. Similar patterns are observed for immigrants of other national origins, who are even less concentrated with members of their own group. Overall, no immigrant group defined by national origin forms a majority in any census tract in metropolitan France. Approximately $90 \%$ of Algerians, Moroccans, Tunisians and Turks live in census tracts where they represent fewer than $10 \%$ of residents.

[Insert Fig. 1 here]

In addition, we also found no evidence of ethnic withdrawal at the geocultural level (Fig. 2). More than $90 \%$ of North African immigrants—-the most concentrated group along with Asians-live in census tracts, where they represent less than $20 \%$ of the population. Ninety percent of Sub-Saharan Africans and immigrants from the Middle East live in census tracts, where they represent less than $10 \%$ of the population. No other group forms a majority in the population. These findings confirm the observations of other European studies for the United Kingdom (Finney and Simpson, 2007; Simpson, 2005), Belgium (Kesteloot, 1986), and Germany (Münch, 2009).

\section{[Insert Fig. 2 here]}

\section{6 - An increased proportion of immigrants in the census tracts from 1968 to 2007}

Even if the proportion of individuals from the same national or geocultural origin in the census tract has remained relatively low, this stability might hide the fact that immigrants from all origins have clustered increasingly in the same census tracts over time. To 
investigate this possibility, in this section, we document the changes in the proportion of immigrants from all origins across different groups of immigrants by focusing on nonEuropean immigrants.

In 1968, 80\% of non-European immigrants in France lived in neighbourhoods with between $0 \%$ and $20 \%$ immigrants (Fig. 3). Forty years later, only $53 \%$ of immigrants lived in neighbourhoods with less than $20 \%$ immigrants. This implies that, in a paradoxical way, the large increase in the proportion of non-European immigrants in the population from 1968 to 2007 was followed by a decrease in the proportion of non-European immigrants living in census tracts composed of between $0 \%$ and $15 \%$ immigrants. By contrast, we observe a large increase in the proportion living in census tracts, composed of between $20 \%$ and $40 \%$ immigrants. However, more than half of non-European immigrants live in census tracts composed of less than $20 \%$ immigrants, and only one-fifth live in census tracts that could be characterised as "immigrant enclaves", with more than $30 \%$ of immigrants in the population.

[Insert Fig. 3 here]

Across different groups, in 2007, the distribution of the proportion of immigrants in census tracts is similar for all non-European immigrants (Fig. 4). Only ten percent of North Africans, Sub-Saharan Africans and Asians live in census tracts with more than $35 \%$ of immigrants. Less than 5\% of these immigrants live in census tracts with more than $40 \%$ immigrants. Moreover, less than $1 \%$ of individuals from these three groups of non-European immigrants live in census tracts where immigrants form a majority of the population, and no census tract is comprised of more than $55 \%$ immigrants.

[Insert Fig. 4 here]

At the extreme end of the distribution, among the 10 census tracts with the highest proportion of immigrants in France in 2007, 9 census tracts are located in the Paris region, 
with 7 of these in the département of Seine-Saint-Denis (the so-called "9-3" area). In these census tracts located in Clichy-sous-Bois, La Courneuve, Aubervilliers, Saint-Denis, Paris $13^{\mathrm{e}}$ (the so-called "Chinatown" census tract), Creil and Montpellier in the south of France, immigrants represent a majority (between $50 \%$ and $60 \%$ ) of the population. They polarise much of the media attention and are often used to infer the current state of segregation in France. However, far from representing the situation of many immigrants, these census tracts appear to be extreme and atypical examples. The proportion of non-European immigrants living in census tracts comprised of more than 50\% immigrants has declined over this period, from $1.3 \%$ in 1975 to $0.6 \%$ in 2007.

In sum, the most striking feature of the previous findings is the high level of sociospatial dispersion of immigrants of all origins. This implies that most non-European immigrants in France have been residentially incorporated. Incidentally, such an inclusion into the French social fabric might have made immigrants more visible and exposed them to xenophobia. Had their spatial isolation been real, they would have disappeared from the notice of native-born citizens and from public discourse (Wacquant, 2007).

\section{7 - Both the concentration and the proportion of immigrants in the census tract diminishes over time}

As discussed earlier, the residential incorporation of immigrants in the host society might increase with the length of residence. To quantify this process, we investigate the relationship between spatial segregation and length of stay in France using data from 1999 and 2007 Censuses in which information concerning the arrival year is available.

As the size of the sub-groups varies widely, for a correct interpretation, it is particularly important to focus on the corrected indices because observed indices depend strongly on the size of the subgroups. For most non-European groups, we found that corrected dissimilarity indexes tend to decrease with length of stay (Table 3). In particular, for Sub- 
Saharan African immigrants or immigrants from East Asia, there is a 10 point gap in 2007 and in 1999 between immigrants who had arrived more than 30 years prior and those who had arrived in the past five years. However, differences are smaller for immigrants from North Africa. After a decrease for the first 20 years of residence in 2007, the index increases by 3 point again. For immigrants from southern Europe, no clear changes over time are observed, but their concentration levels are very low and seem independent of their length of residence.

\section{[Insert Table 3 here]}

Next, we investigate how the characteristics of the census tract vary with length of stay in France while controlling for the effect of differences in observable characteristics across immigrants groups over time (Table 4). Two linear regressions estimate the likelihood that in 1999 and 2007, immigrants from different geocultural groups live in a segregated census tract. The dependent variables are the proportion in the census tract of immigrants either from the same geocultural origin or from all origins. We estimate a different intercept for each geocultural group and length of residence, thus implying that these estimates can be interpreted as the average of the group conditional on other characteristics. Control variables included in the model are age and age squared, national origin, qualifications, sociooccupational category correlated with employment status and size of household (i.e., number of children). Fixed effects for each urban unit were also introduced to absorb the systematic differences in the proportion of migrants in the population across urban areas. To save space, we only report the coefficients concerning the effects of the length of residence in France and age.

\section{[Insert Table 4 here]}

These results reveal a clear general trend: when the length of residence in France increases, immigrants tend live in census tracts with a lower proportion of immigrants from their own group and from all origins. For the proportion of immigrants from their own group, 
the effects are between 1\% for subs-Saharan Africans in 2007 to $0.2 \%$ in 1999. The pattern is similar in 1999 and 2007 for North Africans and immigrants from the Middle East, but incorporation seems more extensive for immigrants from East Asia and Sub-Saharan Africa in 2007.

In Columns 3 and 4, we obtain a larger effect of the length of residence in the proportion of immigrants from all origins in the census tract, with a $2 \%$ difference for North Africa and East Asia after 30 years in France. Interestingly, in 1999, we observe broadly similar incorporation patterns across groups than in 2007 but we tend to find a lower effect of the length of residence for Sub-Saharan Africans. Overall, the evidence suggests that length of residence affects both the concentration (Table 3) and the census tract characteristics (Table 4). While the estimated effect on concentration for some groups is important (approximately 10 point decrease for Asia and Sub-Saharan Africa), we find a U-shape pattern for North Africans in 2007 which probably reflects important changes in composition of this group over time. By contrast, the effects on the share of immigrants in the census tract controlling for characteristics observed (Table 4) are modest but real and observed for all groups with broadly similar intensities.

Obviously, a major limitation of these results is that they potentially confound the effect of changes in the composition of individuals across cohorts with the true effect of length of residence on spatial incorporation. Further research on this point, in particular studies using panel data, would be needed to disentangle the respective role of each factor.

\section{8-Conclusion}

The growth in the proportion of immigrants in the population between 1968 and 2007 has increased the proportion of immigrants in certain census tracts but has had a limited effect on their segregation. The transformation of immigration in France (from southern European to African and Asian) has accompanied a decreasing concentration for most immigrants across 
census tracts since 1968. The large decrease in immigrant concentration that occurred between 1968 and 1975 reflects, among other things, the impact of slum eradication and the increased access to social housing for immigrants (Gastaut, 2004). By contrast, the slight increase in segregation or its stagnation since 1990 suggests the presence of other less favourable factors, particularly unfavourable economic conditions and the impact of unequal immigrant inflows across national groups (Pan Ké Shon, 2013). The increase in the number of migrants has also increased the proportion of concentrated census tracts containing between $25 \%$ and $40 \%$ immigrants in the population. These contradictory trends of the two main dimensions of immigrant segregation are often observed in the rest of Europe.

In addition, our findings clearly suggest that segregation in France is not mono-ethnic. No census tract exists in which Arab, African, or Asian immigrants represent most of the population. The length of residence in the country generally favours the spatial incorporation of migrants, with lower concentrations and lower proportions of immigrants in the census tract over time, but the process is lengthy (Musterd and Ostendorf, 1998), and sometimes, the differences are modest.

The stereotypes of "ghettos" and "failed immigrant integration" of the banlieues in France contradict our empirical findings. A portion of French elites, who retain a biased image of the residential situation of immigrants, influenced to some extent by the image of the American "ghetto", seem unaware of the extent of the spatial incorporation that has occurred silently. The focus of public discourse on the most segregated and most deprived census tracts conceals that most immigrants are living in census tracts that are ethnically varied.

Demonstrating the residential integration of most immigrants does not mean concealing that concentrated neighbourhoods exist. However, it is necessary to impartially report how deeply migrants are segregated. The current excessive dramatisation of 
immigrants' segregation causes the public to perceive immigration as a problem at a time when moderation and clarification are necessary.

\section{Bibliography}

Abramitzky R., Boustan L.-P., and Eriksson K., 2012, Europe's Tired, Poor, Huddled Masses: SelfSelection and Economic Outcomes in the Age of Mass Migration, American Economic Review, 102(5): 1832-1856 ; DOI:10.1257/aer.102.5.1832

Andersson R., Bråmå A. and Holmqvist E., 2010, Conteracting segregation: Swedish policies and Experiences, Housing studies, Vol. 25(2), 237-256, DOI: 10.1080/02673030903561859.

Åslund O., Rooth D.-O., 2007, Do when and where matter? Initial labour market conditions and immigrant earnings, The Economic Journal, Vol. 117, № 518, p. 422-448, DOI: 10.1111/j.14680297.2007.02024.

Bell, W. 1954, “A Probability Model for the Measurement of Ecological Segregation”, Social Forces $43,357-64$

Bell B., Machin S., 2013, Immigrant Enclaves and Crime, Journal of Regional Science, Vol 53, Issue 1, 118-141, DOI: 10.1111 jors. 12003

Bolt G., van Kempen R. and van Ham M., 2008, Minority Ethnic Groups in the Dutch Housing Market: Spatial Segregation, Relocation Dynamics and Housing Policy, Urban Studies, 45: 13591384, DOI: $10.1177 / 0042098008090678$.

Bonnal L., Boumahdi R., and Favard P., 2012, Nonexpected discrimination: the case of social housing in France. Applied Economics Letters, 19(18), 1909-1916.

Bråmå A., 2008, Dynamics of Ethnic Residential Segregation in Göteborg, Sweden, 1995-2000, Population, Space, and Place, 14:101-117, DOI: 10.1002/psp.479.

Borjas 1985 "Assimilation, Changes in Cohort Quality, and the Earnings of Immigrants," Journal of Labor Economics, vol 3, n4, 463-489. 
Carrington W. J., Troske K. R., 1997, On measuring segregation in samples with small units. Journal of Business \& Economic Statistics, 15(4), 402-409.

Cutler, D. M., Glaeser, E. L., and Vigdor, J. L., 2008, Is the melting pot still hot? Explaining the resurgence of immigrant segregation. The Review of Economics and Statistics, 90(3), 478-497.

Farley J. E., 1995, Race Still Matters The Minimal Role of Income and Housing Cost as Causes of Housing Segregation in St. Louis, 1990. Urban Affairs Review, 31(2), 244-254.

Finney N., Simpson L., 2007, Internal migration and ethnic groups: evidence for the UK from the 2001 Census, Manchester, The University of Manchester, CCSR Working Paper, 2007-04.

Friedrichs J., 1998, Ethnic Segregation in Cologne, Germany, 1984-94, Urban Studies, Vol. 35, № 10, 1745- 1763, DOI: 10.1080/0042098984132.

Gastaut Y., 2004, «Les bidonvilles, lieux d'exclusion et de marginalité en France durant les trente glorieuses », Cahiers de la Méditerranée, 69, URL : http://cdlm.revues.org/829

Kepel, G., 2011, Banlieues de la République, avec Arslan L. et Zouheir S., Institut Montaigne. Kesteloot C., 1986. — Concentration d'étrangers et politique urbaine à Bruxelles, Revue Européenne des Migrations Internationales, Volume 2, Numéro 3, p. 151 - 168.

Kirszbaum T., 2008, Mixité sociale dans l'habitat. Revue de la littérature dans une perspective comparatiste, La documentation française.

Lagrange H., 2006, « Ethnicité » et déséquilibres sociaux en Île-de-France in L'épreuve des inégalités, Hugues Lagrange (dir.), Le Lien Social, PUF, p. 247-282.

Lapeyronnie D., 2008, Ghetto urbain. Ségrégation, violence, pauvreté en France aujourd'hui, Paris, Robert Laffont.

Manley D., and van Ham M., 2011, Choice-based Letting, Ethnicity and Segregation in England, Urban studies, vol. 48, 14, p. 3125-3143, DOI: $10.1177 / 0042098010394685$.

Massey D. S., Denton N. A., 1988, The dimensions of residential segregation, Social forces, 67, 2, pp. 281-315, doi: 10.1093/sf/67.2.281. 
Münch S., 2009. "It's all in the mix"': constructing ethnic segregation as a social problem in

Germany, Journal of Housing and the Built Environment, 24: p. 441-455.

Musterd, S., 2005, Social and ethnic segregation in Europe: levels, causes, and effects. Journal of Urban Affairs, 27(3), 331-348.

Musterd, S. and Ostendorf W., 2009, 'Residential Segregation and Integration in the Netherlands', Journal of Ethnic and Migration Studies, 35: 9, 1515-1532.

Musterd, S. and Ostendorf W., 1998, Segregation, Polarisation and Social Exclusion in Metropolitan Areas in Urban segregation and the welfare state: inequality and exclusion in western cities, Sako Musterd and Wim Ostendorf Eds., London, Routledge, p. 1-14.

Musterd S. \& van Kempen R., 2009. Segregation And Housing Of Minority Ethnic Groups In Western European Cities, Tijdschrift voor Economische en Sociale Geografie, Vol. 100, N ${ }^{\mathrm{o}}$ 4, pp. 559-566.

Pan Ké Shon J.-L., 2010, The ambivalent nature of ethnic segregation in France's disadvantaged neighbourhoods, Urban Studies, 47(8), p. 1603-1623, DOI: 10.1177/0042098009356123.

Pan Ké Shon J.-L., 2013, Quarante ans de ségrégation et d'incorporation des immigrés en France, 1968-2007, Rapport de recherche commandité par le PUCA et l’ACSé, 168 p.

Pan Ké Shon J.-L., Scodellaro C., 2011, « Discrimination et ségrégation ethno-raciale en France », Document de travail Ined, $\mathrm{n}^{\circ} 171$.

Peach, C., 1996, "Does Britain have ghettos?", Transactions of the Institute of British Geographers, New Series, Vol. 21, No. 1, pp. 216-235

Peach, C., 2009, Slippery Segregation: Discovering or Manufacturing Ghettos?, Journal of Ethnic and Migration Studies, 35: 9, 1381 - 1395, DOI: 10.1080/13691830903125885.

Préteceille E., 2009, « La ségrégation ethno-raciale dans la métropole parisienne », Revue française de sociologie, 50(3), p. 489-519.

Safi M., 2009, «La dimension spatiale de l'intégration des populations immigrées (1968-1999)», Revue française de sociologie, 50(3), p. 521-552. 
Simpson L., 2004, Statistics of racial segregation: measures, evidence and policy. Urban Studies,

Volume 41, Number 3, pp. 661-681, DOI: 10.1080/0042098042000178735.

Simpson L., 2005, On the Measurement and Meaning of Residential Segregation: A Reply to Johnston, Poulsen and Forrest, Urban Studies, 42: 1229.

Simpson L., 2007, Ghettos of the mind: the empirical behaviour of indices of segregation and diversity, J. R. Statist. Soc. A, 170, Part 2, pp. 405-424.

Simpson L., Gavalas V., and Finney N., 2008, Population Dynamics in Ethnically Diverse Towns: The Long-term Implications of Immigration, Urban studies, 45(1) 163-183,

DOI: $10.1177 / 0042098007085106$.

Tanter A., Toubon J.-C., 1999, Mixité sociale et politiques de peuplement : genèse de l'ethnicisation des opérations de réhabilitation, Sociétés contemporaines, $\mathrm{n}^{\circ}$ 33-34, pp. 59-86.

Verdugo G., 2011, Public Housing and Residential Segregation of Immigrants in France (1968-1999), Population, Vol. 66, $\mathrm{n}^{\circ}$ 1, p. 171-196.

Verdugo G., 2012, Fragmentation urbaine et chocs économiques : deux déterminants de l'offre de logement sociaux en France, Économie et Statistique, $\mathrm{n}^{\circ} 446$

Verdugo G., 2013, Public Housing Magnets: Public Housing Supply and Immigrants' Location Choices, mimeo.

Wacquant, L., 1989, Pour en finir avec le mythe des «Cités-ghettos ». Les différences entre la France et les Etats-Unis., Les Annales de la Recherche Urbaine, $\mathrm{n}^{\circ}$ 54, p. 21-30.

Wacquant, L., 2007, Parias urbains, Ghetto, banlieues, Etat. Une sociologie comparée de la marginalité sociale, La Découverte, coll. «La Découverte/Poche ».

Zorlu A. and Latten J., 2009, Ethnic Sorting in The Netherlands, Urban Studies, 46(9), p. 1899-1923, DOI: $10.1177 / 0042098009106023$.

Zorlu A. et Mulder C. H., 2010, Location Choices of Migrant Nest-Leavers: Spatial Assimilation or Continued Segregation?, IZA DP No. 5141 
Table 1 - Indices of dissimilarity \%

A - ...by national origin

\begin{tabular}{lllllll|cccccc}
\hline \multicolumn{5}{c}{ Observed Indices } & & \multicolumn{4}{c}{ Diff. (Observed - Random Indices) } \\
\hline Year & $\mathbf{1 9 6 8}$ & $\mathbf{1 9 7 5}$ & $\mathbf{1 9 8 2}$ & $\mathbf{1 9 9 0}$ & $\mathbf{1 9 9 9}$ & $\mathbf{2 0 0 7}$ & $\mathbf{1 9 6 8}$ & $\mathbf{1 9 7 5}$ & $\mathbf{1 9 8 2}$ & $\mathbf{1 9 9 0}$ & $\mathbf{1 9 9 9}$ & $\mathbf{2 0 0 7}$ \\
\hline Algeria & 53 & 44 & 41 & 40 & 40 & 40 & 41 & 33 & 31 & 29 & 29 & 31 \\
Morocco & 54 & 47 & 44 & 42 & 43 & 41 & 33 & 29 & 30 & 29 & 30 & 30 \\
Tunisia & 43 & 41 & 38 & 38 & 40 & 40 & 26 & 24 & 24 & 23 & 24 & 25 \\
Turkey & 52 & 56 & 56 & 55 & 58 & 55 & 25 & 27 & 34 & 35 & 37 & 38 \\
Italy & 27 & 25 & 24 & 24 & 27 & 27 & 18 & 14 & 13 & 12 & 12 & 12 \\
Spain & 31 & 29 & 26 & 25 & 28 & 28 & 20 & 17 & 13 & 11 & 11 & 10 \\
Portugal & 51 & 37 & 32 & 28 & 30 & 30 & 35 & 26 & 22 & 17 & 18 & 18 \\
\hline
\end{tabular}

B - ...by "geocultural" origin

\begin{tabular}{lllllll|llllll}
\hline \multicolumn{7}{c}{ Observed Indices } & \multicolumn{5}{c}{ Diff. (Observed - Random Indices) } \\
\hline Year & $\mathbf{1 9 6 8}$ & $\mathbf{1 9 7 5}$ & $\mathbf{1 9 8 2}$ & $\mathbf{1 9 9 0}$ & $\mathbf{1 9 9 9}$ & $\mathbf{2 0 0 7}$ & $\mathbf{1 9 6 8}$ & $\mathbf{1 9 7 5}$ & $\mathbf{1 9 8 2}$ & $\mathbf{1 9 9 0}$ & $\mathbf{1 9 9 9}$ & $\mathbf{2 0 0 7}$ \\
\hline Sub. Africa & 47 & 51 & 46 & 41 & 38 & 37 & 25 & 29 & 31 & 27 & 26 & 28 \\
North Africa & 43 & 38 & 37 & 36 & 38 & 38 & 33 & 29 & 29 & 28 & 30 & 31 \\
East Asia & 60 & 57 & 51 & 44 & 41 & 38 & 20 & 24 & 33 & 30 & 27 & 26 \\
Middle East & 47 & 50 & 45 & 40 & 45 & 42 & 24 & 26 & 28 & 25 & 28 & 28 \\
South-Europe & 25 & 24 & 21 & 20 & 22 & 22 & 18 & 16 & 14 & 12 & 13 & 13 \\
Other European & 26 & 27 & 27 & 26 & 27 & 27 & 16 & 16 & 16 & 15 & 14 & 16 \\
\hline
\end{tabular}

Sources: French censuses.

Reference population: Urban units of more than 50,000 inhabitants.

Notes: The left panel displays the weighted average dissimilarity indexes across urban units.

The right panel displays the difference between the observed and a random index weighted average. A break in series occurred in 2007 with the implementation of the redesigned

Census. 
Table 2 - Indices of isolation \%

\section{A - ...by national origin}

\begin{tabular}{lllllll|cccccc}
\hline \multicolumn{5}{c}{ Observed Indices } & & \multicolumn{5}{c}{ Diff. (Observed - Random Indices) } \\
\hline Year & $\mathbf{1 9 6 8}$ & $\mathbf{1 9 7 5}$ & $\mathbf{1 9 8 2}$ & $\mathbf{1 9 9 0}$ & $\mathbf{1 9 9 9}$ & $\mathbf{2 0 0 7}$ & $\mathbf{1 9 6 8}$ & $\mathbf{1 9 7 5}$ & $\mathbf{1 9 8 2}$ & $\mathbf{1 9 9 0}$ & $\mathbf{1 9 9 9}$ & $\mathbf{2 0 0 7}$ \\
\hline Algeria & 5.8 & 6.0 & 5.5 & 4.3 & 4.2 & 5.0 & 4.2 & 3.9 & 3.2 & 2.3 & 2.2 & 2.7 \\
Morocco & 3.3 & 3.5 & 3.5 & 3.7 & 4.6 & 5.1 & 2.8 & 2.6 & 2.3 & 2.4 & 3.0 & 3.1 \\
Tunisia & 2.2 & 2.5 & 2.6 & 2.4 & 2.3 & 2.3 & 1.3 & 1.5 & 1.5 & 1.3 & 1.3 & 1.4 \\
Turkey & 1.6 & 2.3 & 2.5 & 2.9 & 3.7 & 3.7 & 1.2 & 1.9 & 1.9 & 2.2 & 2.9 & 2.8 \\
Italy & 5.3 & 4.4 & 3.5 & 2.9 & 2.3 & 2.1 & 1.2 & 1.1 & 0.8 & 0.7 & 0.7 & 0.6 \\
Spain & 3.8 & 3.4 & 2.5 & 2.0 & 1.6 & 1.3 & 1.2 & 1.1 & 0.7 & 0.5 & 0.4 & 0.4 \\
Portugal & 4.8 & 4.5 & 3.8 & 3.1 & 3.1 & 2.9 & 3.7 & 2.2 & 1.5 & 1.1 & 1.1 & 1.1 \\
\hline
\end{tabular}

B - ...by "geocultural” origin

\begin{tabular}{llllllll|llllll}
\hline \multicolumn{5}{c}{ Observed Indices } & \multicolumn{5}{c}{ Diff. (Observed - Random Indices) } \\
\hline Year & $\mathbf{1 9 6 8}$ & $\mathbf{1 9 7 5}$ & $\mathbf{1 9 8 2}$ & $\mathbf{1 9 9 0}$ & $\mathbf{1 9 9 9}$ & $\mathbf{2 0 0 7}$ & $\mathbf{1 9 6 8}$ & $\mathbf{1 9 7 5}$ & $\mathbf{1 9 8 2}$ & $\mathbf{1 9 9 0}$ & $\mathbf{1 9 9 9}$ & $\mathbf{2 0 0 7}$ \\
\hline Sub. Africa & 2.5 & 2.7 & 3.3 & 3.3 & 3.6 & 4.9 & 2.0 & 2.2 & 2.3 & 2.0 & 1.8 & 2.3 \\
North Africa & 6.8 & 7.9 & 8.1 & 7.4 & 7.9 & 9.1 & 4.3 & 4.4 & 4.1 & 3.5 & 4.0 & 4.6 \\
East Asia & 0.9 & 1.0 & 4.0 & 4.2 & 4.4 & 4.5 & 0.7 & 0.7 & 3.3 & 3.0 & 2.9 & 2.8 \\
Middle East & 1.6 & 2.2 & 2.3 & 2.6 & 3.2 & 3.4 & 1.1 & 1.7 & 1.5 & 1.6 & 2.2 & 2.2 \\
South-Europe & 7.4 & 7.2 & 5.9 & 4.9 & 4.3 & 4.0 & 1.8 & 1.8 & 1.3 & 1.0 & 1.0 & 1.0 \\
Other European & 4.2 & 3.8 & 3.2 & 2.8 & 2.6 & 3.1 & 1.2 & 1.3 & 1.1 & 0.9 & 0.9 & 1.0 \\
\hline
\end{tabular}

Sources: French censuses.

Reference population: Urban units of more than 50,000 inhabitants.

Notes: The left panel displays the weighted average isolation indexes across urban units. The right panel displays the difference between the observed and a random index weighted average. A break in series occurred in 2007 with the implementation of the redesigned Census. 
Table 3 - Effect of years of residence on segregation: Indices of dissimilarity \%

\begin{tabular}{|c|c|c|c|c|c|c|c|c|c|c|c|c|c|}
\hline & & \multicolumn{6}{|c|}{ Observed indices } & \multicolumn{6}{|c|}{$\begin{array}{c}\text { Difference } \\
\text { (Observed - Random Indices) }\end{array}$} \\
\hline \multicolumn{2}{|c|}{$\begin{array}{l}\text { Years of residence in } \\
\text { France }\end{array}$} & $0-5$ & $06-10$ & $11-15$ & $16-20$ & $21-30$ & $>30$ & $0-5$ & $6-10$ & $\begin{array}{l}11- \\
15\end{array}$ & $\begin{array}{l}16- \\
20\end{array}$ & $21-30$ & $>30$ \\
\hline \multirow[t]{2}{*}{ Sub. Africa } & 2007 & 41 & 43 & 47 & 45 & 41 & 44 & 26 & 23 & 19 & 20 & 20 & 16 \\
\hline & 1999 & 55 & 62 & 64 & 63 & 60 & 67 & 27 & 26 & 22 & 18 & 15 & 10 \\
\hline \multirow[t]{2}{*}{ North Africa } & 2007 & 41 & 45 & 47 & 44 & 41 & 37 & 29 & 26 & 22 & 21 & 24 & 25 \\
\hline & 1999 & 40 & 53 & 54 & 52 & 45 & 46 & 27 & 30 & 22 & 28 & 28 & 32 \\
\hline \multirow[t]{2}{*}{ East Asia } & 2007 & 46 & 53 & 54 & 52 & 45 & 46 & 26 & 25 & 23 & 21 & 24 & 18 \\
\hline & 1999 & 62 & 75 & 75 & 67 & 71 & 66 & 36 & 25 & 28 & 20 & 11 & 12 \\
\hline \multirow[t]{2}{*}{ Middle East } & 2007 & 50 & 59 & 62 & 56 & 48 & 51 & 27 & 22 & 19 & 22 & 20 & 17 \\
\hline & 1999 & 60 & 74 & 78 & 77 & 69 & 57 & 21 & 19 & 14 & 13 & 12 & 10 \\
\hline \multirow[t]{2}{*}{ South-Europe } & 2007 & 32 & 53 & 50 & 48 & 39 & 24 & 14 & 12 & 13 & 13 & 9 & 13 \\
\hline & 1999 & 25 & 57 & 64 & 67 & 34 & 20 & 9 & 17 & 12 & 9 & 9 & 7 \\
\hline
\end{tabular}

Sources: French censuses.

Reference population: Urban units of more than 50,000 inhabitants.

Notes: The left panel displays the weighted average dissimilarity indexes across urban units. The right panel displays the difference between the observed and a random index weighted average. 
Table 4 - The effect of length of residence in France on the share of immigrants in the census tract in 2007 and 1999 for non-Europeans. Extract, OLS estimates.

\begin{tabular}{|c|c|c|c|c|c|}
\hline \multirow{2}{*}{\multicolumn{2}{|c|}{\begin{tabular}{|l|l} 
& Dependent variable \\
Length of residence in France
\end{tabular}}} & \multicolumn{2}{|c|}{$\begin{array}{l}\text { Share of immigrants } \\
\text { from the same } \\
\text { geocultural origin in } \\
\text { the census tract }\end{array}$} & \multicolumn{2}{|c|}{$\begin{array}{l}\text { Share of immigrants } \\
\text { from all origins in the } \\
\text { census tract }\end{array}$} \\
\hline & & 2007 & 1999 & 2007 & 1999 \\
\hline \multirow{8}{*}{$\begin{array}{l}\text { North } \\
\text { Africa }\end{array}$} & $>30$ years & 8.11 & 7.23 & 10.7 & 9.5 \\
\hline & & $(2.17)$ & $(2.49)$ & $(2.51)$ & $(2.57)$ \\
\hline & $21-30$ years & 8.13 & 7.83 & 11.13 & 10.31 \\
\hline & & $(2.17)$ & $(2.49)$ & $(2.52)$ & $(2.56)$ \\
\hline & $11-20$ years & 8.43 & 7.84 & 11.76 & 10.68 \\
\hline & & $(2.17)$ & $(2.49)$ & $(2.51)$ & $(2.56)$ \\
\hline & $<10$ years & 8.83 & 8.02 & 12.74 & 11.01 \\
\hline & & $(2.16)$ & $(2.49)$ & $(2.50)$ & $(2.56)$ \\
\hline \multirow{8}{*}{$\begin{array}{l}\text { Sub- } \\
\text { Saharan } \\
\text { Africa }\end{array}$} & $>30$ years & 4.00 & 3.56 & 11.05 & 10.12 \\
\hline & & $(2.17)$ & $(2.49)$ & $(2.52)$ & $(2.57)$ \\
\hline & 21-30 years & 4.39 & 3.55 & 11.57 & 10.18 \\
\hline & & $(2.18)$ & $(2.49)$ & $(2.51)$ & $(2.57)$ \\
\hline & $11-20$ years & 4.72 & 3.80 & 12.23 & 10.79 \\
\hline & & $(2.17)$ & $(2.49)$ & $(2.51)$ & $(2.57)$ \\
\hline & $<10$ years & 5.04 & 3.76 & 12.55 & 10.70 \\
\hline & & $(2.17)$ & $(2.49)$ & $(2.51)$ & $(2.56)$ \\
\hline \multirow{8}{*}{ East-Asia } & $>30$ years & 4.37 & 3.76 & 10.21 & 10.06 \\
\hline & & $(2.25)$ & $(2.49)$ & $(2.55)$ & $(2.57)$ \\
\hline & 21-30 years & 4.27 & 4.60 & 11.57 & 10.27 \\
\hline & & $(2.25)$ & $(2.53)$ & $(2.54)$ & $(2.59)$ \\
\hline & $11-20$ years & 4.55 & 4.44 & 13.09 & 11.48 \\
\hline & & $(2.20)$ & $(2.53)$ & $(2.52)$ & $(2.59)$ \\
\hline & $<10$ years & 4.72 & 4.18 & 12.54 & 11.62 \\
\hline & & $(2.18)$ & $(2.50)$ & $(2.51)$ & $(2.58)$ \\
\hline \multirow{12}{*}{$\begin{array}{c}\text { Middle } \\
\text { East }\end{array}$} & $>30$ years & 2.65 & 3.02 & 10.81 & 9.89 \\
\hline & & $(2.18)$ & $(2.49)$ & $(2.52)$ & $(2.57)$ \\
\hline & 21-30 years & 2.57 & 3.21 & 10.28 & 10.57 \\
\hline & & $(2.18)$ & $(2.50)$ & $(2.52)$ & $(2.57)$ \\
\hline & $11-20$ years & 2.76 & 3.24 & 11.26 & 10.65 \\
\hline & & $(2.18)$ & $(2.50)$ & $(2.51)$ & $(2.57)$ \\
\hline & $<10$ years & 3.53 & 3.49 & 12.58 & 11.35 \\
\hline & & $(2.17)$ & $(2.49)$ & $(2.50)$ & $(2.57)$ \\
\hline & Age & 0.140 & 0.067 & 0.192 & 0.089 \\
\hline & & $(0.020)$ & $(0.012)$ & $(0.025)$ & $(0.014)$ \\
\hline & $\operatorname{Age}^{2} / 100$ & -0.156 & -0.063 & -0.169 & -0.069 \\
\hline & & $(0.022)$ & $(0.014)$ & $(0.027)$ & $(0.016)$ \\
\hline $\mathbf{N}$ & & 234572 & 178379 & 234572 & 178379 \\
\hline
\end{tabular}


Reference population: Immigrants aged 20-65, household reference persons, Urban Unit>50,000 inhabitants, arrived in France at 20 years old or more.

Source: French 2007 and 1999 census.

Interpretation: OLS estimates of a regression where the dependent variable is the share of immigrants in the neighbourhood from the same geocultural origin (Column $1 \& 2$ ) or from all origins (Column 3 \& 4). Other variables included in the model control for age, age squared, type of household ( 5 categories), education ( 5 categories), SOC plus labour market activity (7 categories) and fixed effects for each urban unit (Complete results are available upon request from the authors). Robust standard errors clustered at the census tract level in parenthesis. 
Fig. 1 - Distribution of immigrants groups by share of immigrants from the same national origin in the census tract in 2007

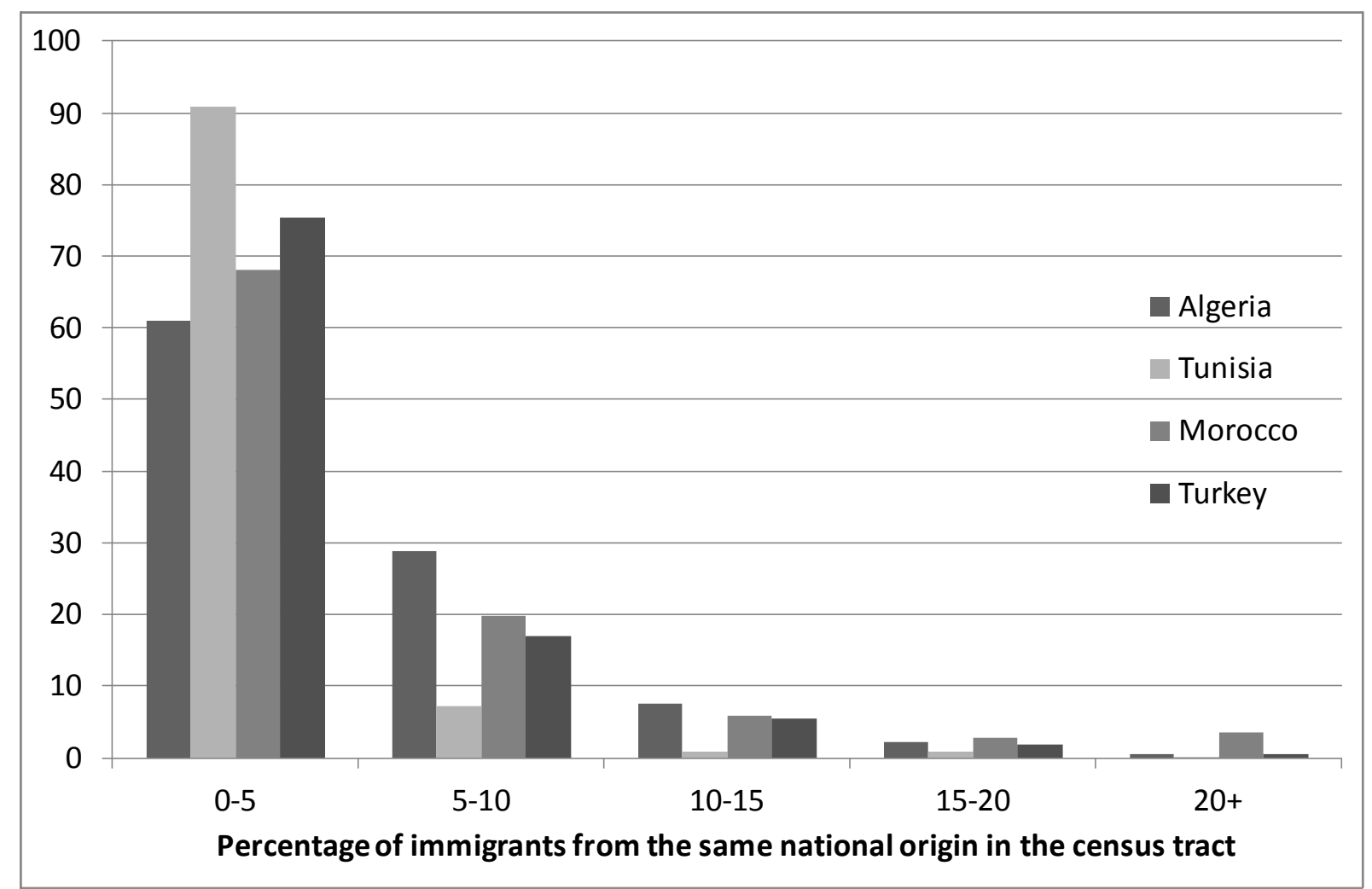

Reference population: Urban units of more than 50,000 inhabitants. 
Fig. 2 - Cumulative distribution of the immigrant group by share of immigrants from the same region in the census tract in 2007

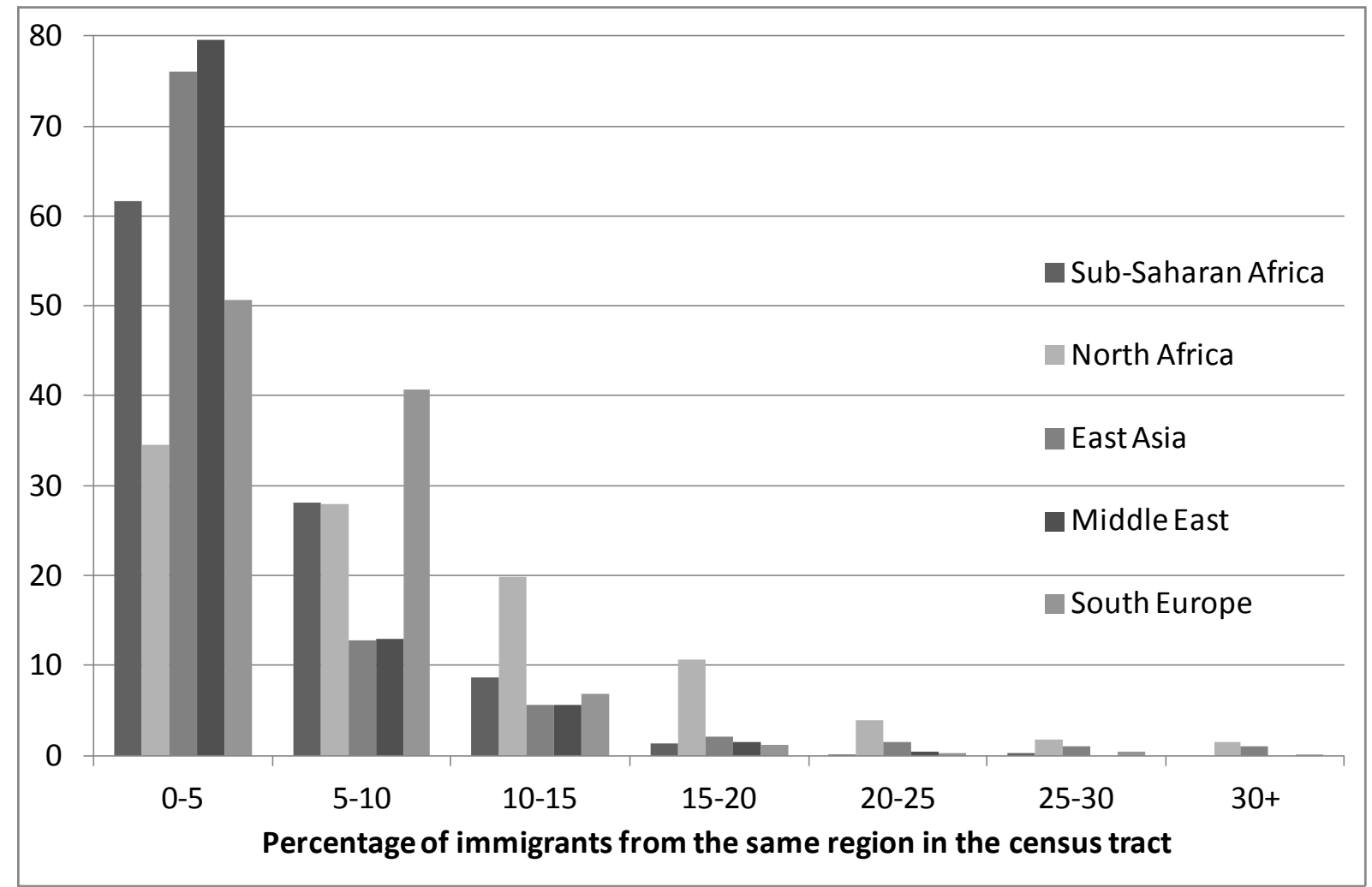

Reference population: Urban units of more than 50,000 inhabitants. 
Fig. 3 - Distribution of non-European immigrants by share of immigrants from all origins in the census tract from 1968-2007

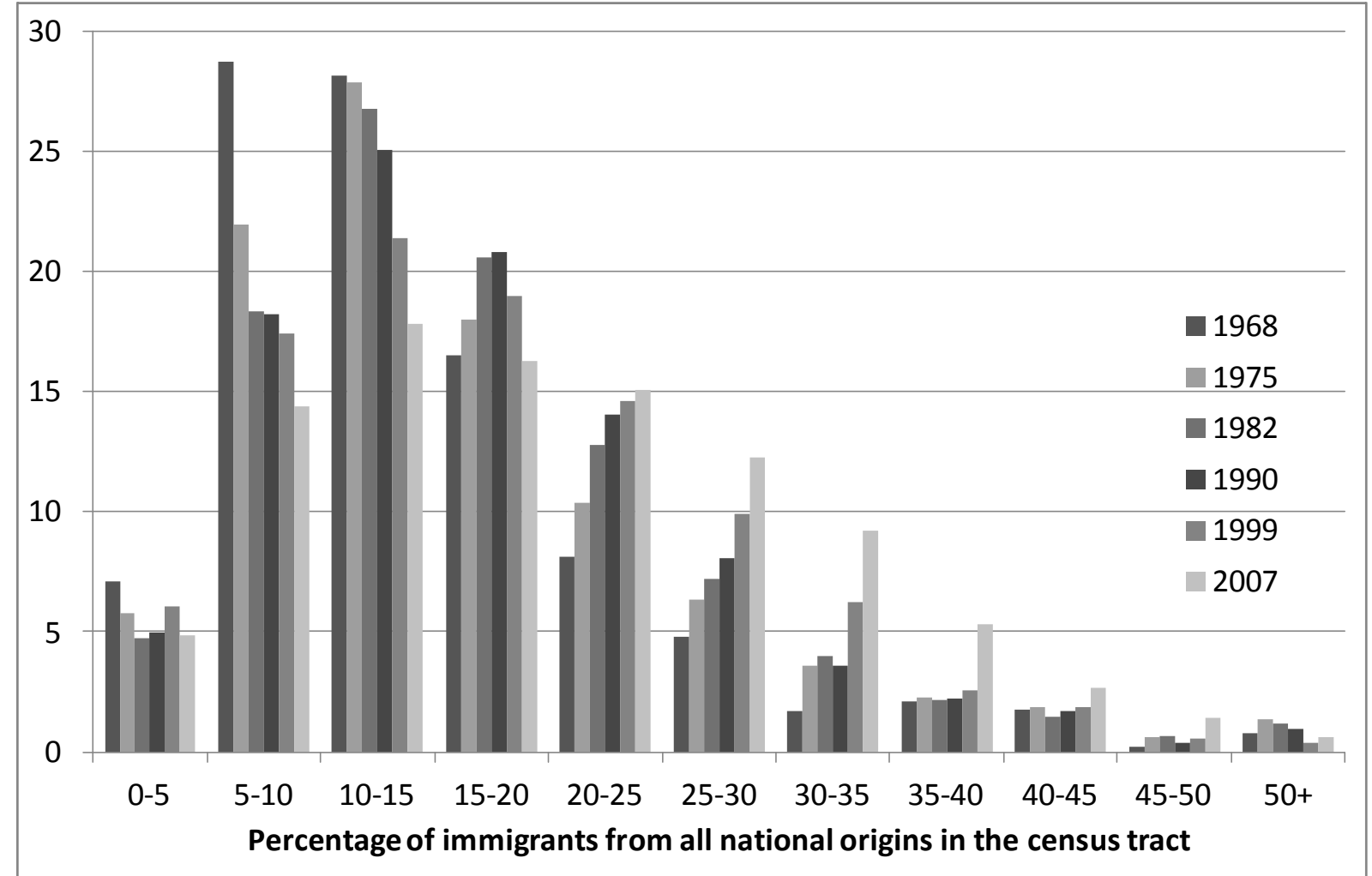

Reference population: Urban units with more than 50,000 inhabitants. 
Fig. 4 - Distribution of immigrant groups and natives by share of immigrants from all origins in the census tract in 2007

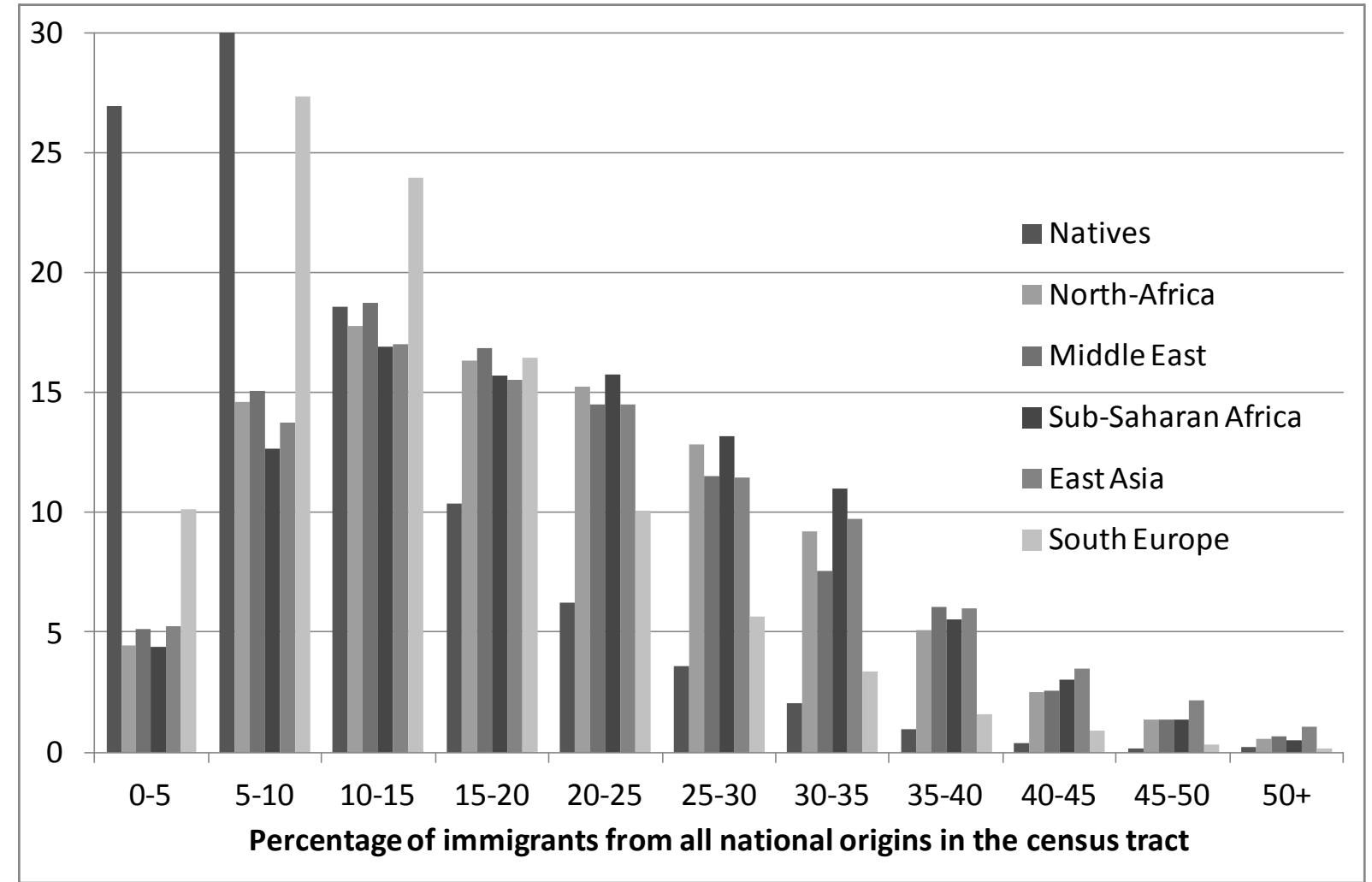

Reference population: Urban units of more than 50,000 inhabitants. 